\title{
Neuroprotective and anti-inflammatory activity of marine sponge extract and HPLC profiling of its components
}

\author{
Da-Eun Kim ${ }^{1} \cdot$ Min-Seon Kim ${ }^{1} \cdot$ Hye Suck An ${ }^{2} \cdot$ Jae Wook Lee ${ }^{3} \cdot$ Jin-Soo Park ${ }^{1}$ (D)

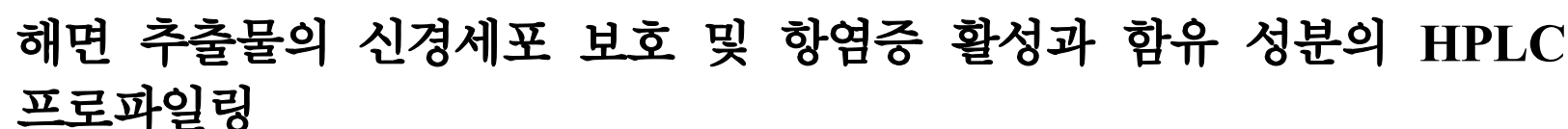

김다은 ${ }^{1} \cdot$ 김민선 $^{1} \cdot$ 안혜숙 $^{2} \cdot$ 이재 $^{\text {욱 }^{3}} \cdot$ 박진수 $^{1}$

Received: 24 December 2020 / Accepted: 30 December 2020 / Published Online: 31 March 2021

(C) The Korean Society for Applied Biological Chemistry 2021

\begin{abstract}
Marine sponges contain pharmacologically attractive substances that exhibit strong cytotoxicity and are used as materials to isolate potential drug candidates. However, with a growing interest in marine ecosystem conservation, it is becoming increasingly difficult to gather a sponge for natural product research. To build a database to cope with this issue, we measured the neuroprotective and anti-inflammatory activity of 181 sponge extracts. As a result, we found 17 samples with neuroprotective effects and 14 samples with anti-inflammatory effects. In addition, high-performance liquid chromatography (HPLC) analysis was performed to compare the components contained in each sample, and based on HPLC profiles, a dendrogram according to similarity was created. The results of this study suggested the possibility of
\end{abstract}

Da-Eun Kim and Min-Seon Kim are contribute equally to this work.

Jin-Soo Park $(\bowtie)$

E-mail: jinsoopark@kist.re.kr

${ }^{1}$ Natural Product Informatics Research Center, Korea Institute of Science and Technology, Gangneung 25451, Republic of Korea

${ }^{2}$ Marine Biology Research Division, National Marine Biodiversity Institute of Korea, 75, Jangsan-ro 101-gil, Janghang-eup, Seocheon-gun, Chungcheongnam-do 33662, Republic of Korea

${ }^{3}$ Natural Product Research Center, Korea Institute of Science and Technology, Gangneung 25451, Republic of Korea

This is an Open Access article distributed under the terms of the Creative Commons Attribution Non-Commercial License (http://creativecommons. org/licenses/by-nc/3.0/) which permits unrestricted non-commercial use, distribution, and reproduction in any medium, provided the original work is properly cited. discovering the active compounds in the sponge and laid the basis for efficient research on the sponge.

Keywords Anti-inflammatory activity $\cdot$ High-performance liquid chromatography profiling $\cdot$ Neuroprotective activity $\cdot$ Sponge

서 론

의약후보물질을 탐색하는 천연물 연구는 전통적으로 생약을 비 롯한 육상 식물과 토양 방선균, 진균 등을 포함하는 미생물을 중심으로 수행되어 현재 많은 연구결과가 보고되어 있다[1]. 한 편, 새로운 화합물 골격을 발굴하기 위하여 새로운 환경의 생 물 자원에 대한 연구의 필요성이 부각되어 육상 생물에서 찾아 보기 어려운 유효한 생리활성을 가지는 해양환경의 생물에 대 한 천연물 연구가 선진국을 중심으로 활발하게 수행되고 있다. 그 결과 비교적 짧은 연구기간에도 불구하고 해양생태계를 구 성하고 있는 다양한 생물 종에 대한 연구는 폭발적으로 발전하 여 이미 15,000 여 신 물질이 해양의 동식물 및 미생물에서 발 견되었다[2]. 또한, 육상 환경에 비하여 해양 환경은 높은 변동 성의 생태환경 변이에 따른 특이 생물 종이 다양하게 분포하고, 외부 감염에 대한 방어 기작이 발달되어있기 때문에 뛰어난 생 리활성을 나타내는 물질들이 꾸준히 보고되고있다[3-5]. 이들 중, 특히 해면동물 유래의 생리활성을 가지는 신 물질은 발견 빈도 가 높은 편으로 천연물연구에서 많은 관심을 받고 있다[6].

해면동물 유래의 천연물은 alkaloids, polyketides, steroids, saponines, terpenoids, nucleosides 등 거의 모든 생합성 기원의 물질을 포괄할 정도로 다양하며[7,8], 이들은 주로 강력한 세포 
독성을 나타내어 면역억제제(discodermolide), 항암제(halichodrin), 항진균제, 소염진통제 등의 소재로서 가치가 증명되고있다 $[9,10]$. 그러나, 해양생태계 보전에 대한 관심과 우려가 커지고 있는 상 황에서 천연물연구를 위한 해면동물 확보는 더욱 어려워지고 있다. 이러한 문제에 대응하기 위하여 본 연구진은 해면동물 추출물 에 대한 생리활성 및 성분프로파일 분석 데이터베이스를 구축하 여 자원의 가치 평가 및 분석을 용이하게 하고, 불필요한 생물 자원 소비를 줄여 해양생태계 보존 및 효율적인 해면동물자원 연구를 가능하게 함으로서 해결점을 찾고자 하였다. 이를 위해 국립해양생물자원관으로부터 해면동물 추출물을 분양 받은 후 추 출물의 기초생리활성과 high-performance liquid chromatography (HPLC) 분석을 수행하였고, 이에 대한 결과를 보고하여 해면동 물자원 연구데이터베이스를 구축하는 기초를 마련하고자 한다.

\section{재료 및 방법}

\section{시약 및 기구}

메탄올, 아세토니트릴, 물은 Thermo Fisher Scientific (Waltham, MA, USA)의 HPLC등급을, formic acid는 Thermo Fisher Scientific의 LC-MS용을 사용하였다. 고체상 추출카트리지는 Waters (Milford, OH, USA)의 Sep-Pak Plus tC18 Environmental cartridge $(900 \mathrm{mg})$ 을 사용하였고 용출은 실린지를 이용하였다.

\section{사용 기기}

HPLC 및 electrospray ionization mass spectrometry 분석은 Agilent Technologies 1200 series/Agilent 6120 Quadrupole LC/MS (Agilent Technologies, Inc., Santa Clara, CA, USA) 을 사용하였고, 분석에 사용된 column은 Luna C18(2) $5 \mu \mathrm{m}$ column $4.6 \times 150 \mathrm{~mm}$ (Phenomenex Inc., Torrance, CA, USA) 를 사용하였다. 전처리 시료의 농축을 위하여 SpeedVac concentrator (Thermo Fisher Scientific, San Jose, CA, USA) 를 사용하였다.

\section{시료 전처리}

사용할 Sep-Pak 카트리지는 먼저 에탄올 $5 \mathrm{~mL}$, 증류수 $5 \mathrm{~mL}$ 을 흘려주어 활성화시킨 후, 제공받은 해면추출물 약 $10 \mathrm{mg}$ 을 증 류수 $1 \mathrm{~mL}$ 에 충분히 녹인 후 활성화된 카트리지에 흘려 통과 시켰다. 시료를 모두 통과시킨 다음, 수분이 제거되도록 충분히 air-aspiration한 후 에탄올 $2 \mathrm{~mL}$ 로 용출 시켜 염이 제거된 해면 추출물 시료를 조제하였다. 용출된 시료는 HPLC-MS 분석에 사 용하였고, 또한 시료를 농축 후 DMSO (Merck KGaA, Darmstadt, Germany)에 녹여 생리활성 탐색에 사용하였다.

\section{HPLC-MS 분석 및 크로마토그램 변환}

전처리 된 시료는 20 분간, $10-100 \%$ 아세토니트릴-물(v/v)의 기 울기 용리를 이용하여 HPLC-MS 분석하였고, 각각 시료의 254 $\mathrm{nm}$ 에서 측정한 크로마토그램을 스프레드시트로 변환하였다. 각 결과를 BioNumerics 7.5 소프트웨어(bioMérieux company, Marcy-l'Étoile, France)에서 유사도 분석을 실시하였고 distance 는 Pearson's correlation로 계산하여 UPGMA 알고리즘을 이용 하여 dendrogram을 생성하였다.

\section{Nitric oxide (NO) assay}

96 well plate 기준 $2.5 \times 10^{4}$ cell/well이 되도록 Raw264.7 cell 을 분주한 후 $37{ }^{\circ} \mathrm{C}, 5 \% \mathrm{CO}_{2}$ 조건에서 overnight 배양하였다. 이후 화합물을 $50,16.6,5.55 \mu \mathrm{g} / \mathrm{mL}$ 농도로 처리하여 2시간 후 에 lipopolysaccharides (LPS from Escherichia coli 026:B6, Merck $\mathrm{KGaA}$ )를 $1 \mu \mathrm{g} / \mathrm{mL}$ 농도가 되도록 첨가하였고, 24시간 배양하였다. 배양된 세포에 griess reagent (sulfanilamide 1\% $(\mathrm{w} / \mathrm{v})$ in phosphoric acid 5\% (v/v): $N$-(naphthyl)ethylenediamine dihydrochloride $0.1 \%(\mathrm{w} / \mathrm{v})=1: 1)$ 를 첨가하여 상등액과 반응하였 고 Synergy HT multi-mode microplate reader (BioTek Instruments, Inc., Winooski, VT, USA)를 이용하여 $540 \mathrm{~nm}$ 에서 흡광도를 측정하였다. 이후 남은 plate에 EZ-Cytox (DoGenBio., Seoul, Korea)를 $10 \mu \mathrm{L}$ 씩 처리하여 30 분간 $37^{\circ} \mathrm{C}$ 에서 반응하였고 450 $\mathrm{nm}$ 에서 흡광도를 측정하여 세포독성을 확인하였다.

\section{Calcein AM assay}

96 well plate 기준 $3 \times 10^{3}$ cell/well이 되도록 $\mathrm{HT} 22$ cell을 분 주한 후 세포의 밀도가 $40 \%$ 가 될 때까지 $37^{\circ} \mathrm{C}, 5 \% \mathrm{CO}_{2}$ 조 건에서 배양한다. 배양된 세포에 화합물을 $50,16.6,5.5 \mu \mathrm{g} / \mathrm{mL}$ 농도로 처리하여 2시간 후에 glutamate (L-Glutamic acid monosodium salt hydrate, Merck $\mathrm{KGaA}$ 를 $5 \mathrm{mM}$ 농도가 되 도록 첨가하였다. 이후 세포 생존율이 $50 \%$ 가 되었을 때, Invitrogen $^{\mathrm{TM}}$ Calcein, AM (Thermo Fisher Scientific)을 제공 된 지침에 따라 처리하여 세포를 염색하였다. 이후 Operetta ${ }^{\mathrm{TM}}$ (PerkinElmer Inc., Waltham, MA, USA)를 사용하여 염색된 세 포를 계수하였다.

\section{결 과}

\section{해면 추출물의 뇌신경 보호 및 항염중 효능 측정}

본 연구에 사용한 해면추출물은 모두 181 종류로 Table 1 과 같 이 해면동물문에 포함되는 24개 속에 해당하며 Hyrtios 속, Coscinoderma 속, Cinachyrella 속, Hymeniacidon 속, Plakoris 속 이 각각 $26,18,17,17,15$ 점 씩 포함되었다. 이들의 활성데이 터를 수집하기 위해, mouse hippocampal neuronal cell line인 HT22를 이용하여 뇌신경 세포 보호 효능과, mouse macrophage cell line인 Raw264.7을 이용하여 항염증 효능을 분석하였다.

HT22 세포는 산화적 스트레스에 의한 신경 세포사의 메커니 즘을 연구하는 in vitro 모델로 사용되고 있으며, 세포사멸 억제 효과를 측정하여 뇌 질환 예방에 대한 유효 물질을 탐색할 수 있다[11]. 해면 추출물의 신경세포 보호 효능을 조사하기 위해 HT22 세포를 glutamate로 산화스트레스를 유도 후에 해면추출 물을 처리하였으며, 그 결과, 181 개 시료 중 17 개 시료에서 양 성대조군인 $N$-acetyl-L-cysteine 대비 $70 \%$ 이상의 세포 보호 효 과를 나타내었다(Table 2).

Raw264.7 세포는 외부 자극에 의해 염증 반응을 일으켜 nitric oxide $(\mathrm{NO})$ 와 같은 매개물질을 생성하는데, 이들의 억제 효능을 측정함으로서 항염증 성분 탐색에 널리 이용되고 있다 [12]. 해면 추출물의 항염증 효능을 조사하기 위해 Raw264.7 cell line에 LPS를 처리하여 증가한 $\mathrm{NO}$ 를 $1 / 3$ 이하로 줄이면서 세포 생존은 $70 \%$ 이상의 결과를 나타내는 시료를 조사하였다. 
Table 1 Classification and biological activity results of marine sponges

\begin{tabular}{lccclccc}
\hline \hline \multicolumn{1}{c}{ Genus } & \# of Sample & $\begin{array}{c}\text { Neuroprotective } \\
\text { activity }\end{array}$ & $\begin{array}{c}\text { Anti-inflammatory } \\
\text { activity }\end{array}$ & Genus & \# of Sample & $\begin{array}{c}\text { Neuroprotective Anti-inflammatory } \\
\text { activity }\end{array}$ \\
\hline Callyspongia & 11 & 1 & & Sarcotragus & 3 & - & - \\
Cinachyrella & 17 & 4 & 1 & Spongia & 17 & 2 & 1 \\
Coscinoderma & 18 & 1 & 1 & Stylissa & 9 & - & - \\
Dactylospongia & 10 & - & - & Agelas sp. & 1 & - & - \\
Dysidea & 5 & - & - & Aplysinopsis & 1 & - & - \\
Haliclona & 7 & - & - & Batzella & 1 & - & - \\
Hymeniacidon & 17 & 2 & 1 & Coelocarteria & 1 & - & - \\
Hyrtios & 26 & 1 & 3 & Cymbastela & 1 & - & - \\
Lipastrotethya & 9 & 2 & 1 & Cymbastela & 2 & - & - \\
Pericharax & 3 & - & - & Luffariella & 2 & 1 \\
Pericharax & 3 & - & - & Psendoceratina & 1 & 1 & - \\
Plakortis & 15 & 2 & 2 & Reniochalina & 1 & 1 \\
\hline
\end{tabular}

Samples which have neuroprotective effect is judged as a sample with $70 \%$ or more cell survival of HT22 cell line, and anti-inflammatory effect sample as a sample producing $70 \%$ cell survival and less than $1 / 3$ of NO production in raw cell line

Table 2 Neuroprotective and anti-inflammatory activity results according to species of marine sponges

\begin{tabular}{|c|c|c|c|c|}
\hline Sample No. & Identification & $\begin{array}{l}\text { Neuroprotective } \\
\text { activity (\%) }\end{array}$ & $\begin{array}{l}\text { Anti-inflammatory } \\
\text { activity (NO) }\end{array}$ & $\begin{array}{c}\text { Anti-inflammatory } \\
\text { activity } \\
\text { (Cell viability) }\end{array}$ \\
\hline KIOST3-821 & Callyspngia sp. & 83.195 & 44.425 & 117.350 \\
\hline KIOST1-110 & Cinachyrella sp. & 88.964 & 22.794 & 103.830 \\
\hline KIOST1-242 & Cinachyrella sp. & 79.089 & 24.723 & 94.115 \\
\hline KIOST3-526 & Cinachyrella sp. & 72.819 & 21.627 & 95.659 \\
\hline KIOST3-818 & Cinachyrella sp. & 26.224 & 16.627 & 76.100 \\
\hline KIOST3-913 & Cinachyrella sp. & 70.322 & 32.031 & 97.430 \\
\hline KIOST1-608 & Coscinoderma cavernosa & 53.412 & -4.918 & 70.190 \\
\hline KIOST2-210 & Coscinoderma sp. & 103.935 & 31.056 & 96.457 \\
\hline KIOST2-203 & Hymeniacidon sp. & 57.181 & 12.781 & 88.665 \\
\hline KIOST3-544 & Hymeniacidaon sp. & 83.003 & 24.121 & 74.177 \\
\hline KIOST3-844 & Hymeniacidaon sp. & 84.635 & 35.929 & 113.740 \\
\hline KIOST1-807 & Hyrtios erectus & 1.144 & -9.249 & 87.373 \\
\hline KIOST2-306 & Hyrtios sp. & 54.202 & -3.091 & 96.174 \\
\hline KIOST3-305 & Hyrtios erectus & 73.175 & 3.469 & 35.320 \\
\hline KIOST3-910 & Hyrtios sp. & 29.731 & 10.314 & 109.780 \\
\hline KIOST1-232 & Lipastrotethya sp. & 72.464 & 1.811 & 57.028 \\
\hline KIOST2-207 & Lipastrotethya sp. & 84.795 & 0.602 & 73.045 \\
\hline KIOST2-211 & Plakortis lita & 74.775 & 13.080 & 74.739 \\
\hline KIOST3-123 & Plakortis lita & 93.598 & 7.049 & 39.091 \\
\hline KIOST3-914 & Plakortis sp. & 58.076 & 13.908 & 143.200 \\
\hline KIOST1-630 & Spongia (Spongia) officinalis & 105.750 & 5.603 & 69.816 \\
\hline KIOST3-603 & Spongia sp.1 & 72.852 & 11.456 & 64.165 \\
\hline KIOST1-808 & Stylissa flabeliformis & 3.181 & -7.856 & 83.075 \\
\hline KIOST3-902 & Stylissa sp. & 26.674 & 6.094 & 107.440 \\
\hline KIOST1-713 & Cymbastela stipitata & 0.940 & -6.457 & 85.303 \\
\hline KIOST2-206 & Pseudoceratina purpurea & 74.466 & 15.374 & 89.597 \\
\hline KIOST1-602 & Reniochalina sp. & 74.466 & -6.068 & 38.912 \\
\hline
\end{tabular}




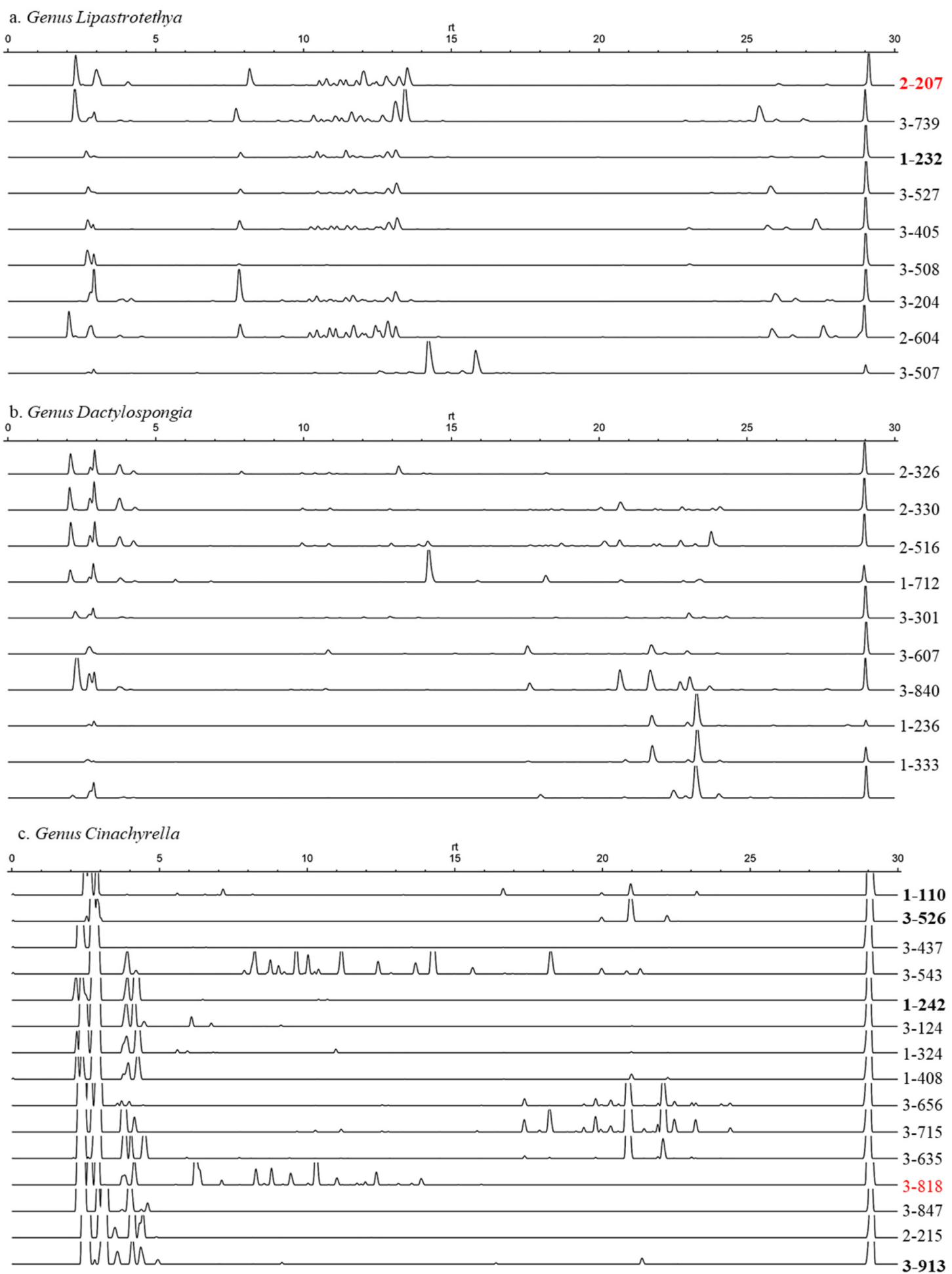

Fig. 1 HPLC chromatogram (254 nm) for each species of sponge (Porifera) a. Genus Lipastrotethya, b. Genus Dactylospongia, c. Genus Cinachyrella

그 결과, 181 개 해면 추출물 시료에서 14 개가 위와 같은 효능 을 보이는 것을 확인하였다(Table 2).

\section{해면 추출물의 HPLC 프로파일링}

활성 분석 결과 같은 속에 속하는 시료 중에서 일부 시료만이
활성을 나타내었기에 같은 속의 해면에 함유 성분이 각기 다를 것으로 예상되어 $\mathrm{HPLC}$ 프로파일링을 통해 각기 다른 활성의 근거를 조사하였다. HPLC 프로파일별 분석결과 Fig. 1과 같이 Lipastrotethya 속은 시료별로 유사한 LC 패턴을 나타낸 반면 Dactylospongia 속과 Cinachyrella 속은 같은 속에서도 함유 성 


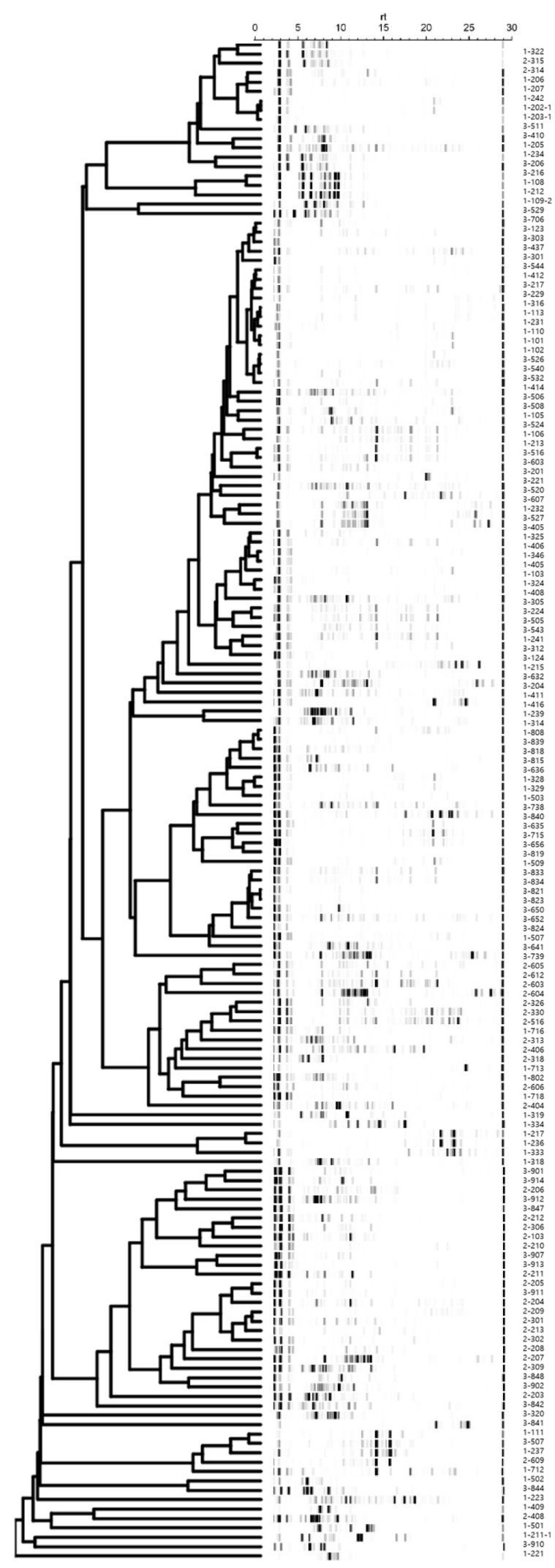

Fig. 2 Classification diagram of 181 sponge extracts according to the HPLC profile (HPLC chromatograms were transformed into band representation)
분이 다양하게 나뉘는 패턴을 보였다. 이와 같은 함유 성분의 차이를 이용하여 성분을 나타내는 HPLC 크로마토그램을 BioNumerics 소프트웨어를 이용하여 유사도에 따라 dendrogram 을 작성하였다(Fig. 2).

\section{고 찰}

본 연구진은 해면 추출물 181 개의 신경세포보호 및 항염증 생 리활성을 확인하였다. 일반적으로 해면 동물의 성분은 세포독성 을 나타내는 경우가 많이 알려져 있고 세포 보호 기반의 생리 활성은 많이 보고되지 않았으나 본 활성검증에서 181 개 시료 중 $9.4 \%$ 시료가 뇌신경 세포 보호 효과를 보이고, $7.7 \%$ 의 시 료가 세포 독성은 낮으면서 항염증지표인 $\mathrm{NO}$ 생성은 저해하였 다. 이는 추후에 해면동물에서의 활성 화합물 발굴 가능성을 시 사하며, 기존의 세포독성 중심의 활성 물질 탐색에서 좀더 다 양한 생리활성물질을 탐색할 수 있는 계기를 제시할 수 있을 것으로 기대한다.

또한, 해양미생물과의 공생관계가 많이 알려진[13] 해면동물 은 동일한 해면동물 속 일지라도 함유 성분의 차이가 크기 때 문에 함유 성분의 프로파일화가 필요하다. 실제 본 연구 결과 같은 속에 포함되는 해면 추출물 간 활성 차이가 크게 나타나 고 HPLC 프로파일도 다른 경우가 확인되었는데, 이는 해면 자 체의 함유 성분 뿐만 아니라 공생 미생물에 의해 생산되는 화 합물의 차이도 있을 것으로 예상되어 해면 연구에서는 해면 공 생 미생물을 함께 연구할 필요성을 제시한다.

본 연구에서는 단파장 $(254 \mathrm{~nm})$ 에서의 HPLC 크로마토그램을 이용하여 유사도에 따른 분류를 실시하였고, 더 나아가 함유 성 분을 가시화할 수 있는 NMR, MS 등의 분광학 자료를 다양하 게 프로파일화한다면 분류가 어려운 해면동물의 동정에 도움이 될 수 있으며 좀 더 다양하고 효율적인 해면동물자원 연구를 수행 할 수 있을 것으로 판단한다.

\section{초 록}

해면동물은 강력한 세포독성을 나타내는 함유성분으로 의약후 보물질 탐색의 중요한 소재로 이용되고 있으나 최근 해양생태 계 보전에 관심이 높아짐에 따라 해면동물 확보는 더욱 어려움 을 겪고 있다. 이러한 경향에 대응하고 해양 천연물연구의 활 성화를 위한 해양생물자원 데이터베이스 구축을 위하여 181 개 해면동물 추출물에 대한 HPLC 프로파일을 생성하고 항염증 및 신경세포보호 활성을 탐색하였다. 이를 통하여 해면동물 추출물 간의 $\mathrm{HPLC}$ 를 통한 함유성분에 따른 클러스터링이 가능하였고 또한 각각 17 개, 14 개 시료에서 항염증 활성과 신경세포보호활 성이 확인되었다. 이와 같은 연구는 해면동물을 포함한 해양생 물자원에서의 효과적인 생리활성 탐색에 도움이 될 것이라고 판 단한다.

Keywords 신경세포보호 · 항염증 · 해면동물 · HPLC 프로파일 
감사의 글 이 논문은 2020 년 해양수산부 재원으로 해양수산과학기술진흥 원의 지원을 받아 수행된 연구임(해외 해양생물자원 개발 및 활용기반 구축, 20170488)

\section{References}

1. Cragg GM, Boyd MR, Khanna R, Newman DJ, Sausville EA (1999) Natural product drug discovery and development. In: Phytochemicals in Human Health Protection, Nutrition, and Plant Defense. 1-29

2. Choi HJ, Kim ND, Jee HJ, Choi YH (2004) Regulation of Bcl-2 Family and Cyclooxygenases by Furanoterpenoids Isolated from a Marine Sponge Sarcotragus sp. in Human Lung Cancer A549 Cells. J Life Sci 14(3): 445-452

3. Shin DY, Kang HS, Bae SJ, Jee HJ, Choi YH (2006) Induction of Apoptosis by Pectenotoxin-2 Isolated from Marine Sponges in U937 Human Leukemic Cells. J Mar Biosci Biotechnol 1(2): 63-70

4. Hentschel U, Fieseler L, Wehrl M, Gernert C, Steinert M, Hacker J, Horn M (2003) Microbial diversity of marine sponges. In: Sponges (Porifera) 2003: 59-88

5. Blunt JW, Copp BR, Munro MH, Northcote PT, Prinsep MR (2003) Marine natural products. Nat Prod Rep 20(1): 1-48

6. Proksch P, Ebel R, Edrada R, Wray V, Steube K (2003) Bioactive natural products from marine invertebrates and associated fungi. In: Sponges (porifera) 117-142
7. Hu GP, Yuan J, Sun L, She ZG, Wu JH, Lan XJ, Zhu X, Lin YC, Chen SP (2011) Statistical research on marine natural products based on data obtained between 1985 and 2008. Mar Drugs 9(4): 514-525

8. Leal MC, Puga J, Serôdio J, Gomes NC, Calado R (2012) Trends in the discovery of new marine natural products from invertebrates over the last two decades-where and what are we bioprospecting? PLOS ONE 7(1): e30580

9. Rangel M, de Sanctis B, de Freitas JC, Polatto JM, Granato AC, Berlinck RG, Hajdu E (2001) Cytotoxic and neurotoxic activities in extracts of marine sponges (Porifera) from southeastern Brazilian coast. J Exp Mar Biol Ecol 262(1): 31-40

10. Azcuna M, Tun JO, Yap HT, Concepcion GP (2018) Callyspongia samarensis (Porifera) extracts exhibit anticancer activity and induce bleaching in Porites cylindrica (Scleractinia). Chem Ecol 34(5): 397-411

11. Schmidt P, Holsboer F, Spengler D (2001) $\beta 2$-adrenergic receptors potentiate glucocorticoid receptor transactivation via $G$ protein $\beta \gamma$ subunits and the phosphoinositide 3-kinase pathway. Mol Endocrinol 15(4): 553-564

12. Yoon YI, Chung MY, Hwang JS, Goo TW, Ahn MY, Lee YB, Han MS, Yun EY (2014) Anti-inflammatory effect of Oxya chinensis sinuosa ethanol extract in LPS-induced Raw264.7 cells. J Life Sci 24(4): 370 376

13. Park SH, Kim JY, Kim YJ, Heo MS (2014) Phylogenetic Diversity of Bacterial Community Inhabited in Callyspongia elegans. Korean J Microbiol 50(2): 152-157 